that high circulating levels of isoniazid based on this inherited metabolic variation induce neuropathy, as do the high levels of circulating nitrofurantoin sometimes encountered in the chemotherapy of chronic kidney infections in the presence of renal failure. But in the case of isoniazid the genetically determined basis of the toxic circulating levels is especially remarkable, and may have implications for other kinds of poisoning where familial susceptibility has been observed. Thalidomide neuropathy is an example from the field under discussion.

Other types of toxic neuropathy are at present the subject of active biochemical study, though the results so far obtained have thrown less light on the general problems concerned than in the two instances mentioned above. Morphological and physiological investigations present fewer intrinsic difficulties than attempts to unravel chemical pathogenesis, especially since we have so little certain knowledge of the intimate chsmistry of the normal peripheral nervous system, but the biocnemical approach undoubtedly has greater potentialities in relation both to aetiology and to ultimate therapeutic possibilities.

\section{Summary}

Although polyneuritis is usually regarded as a disorder of nerve fibres, these fibres are in fact the long processes of neurones situated in the spinal cord and posterior root ganglia. Some polyneuritic lesions primarily affect the nerve fibre at intervals along its length. In others peripheral dying back of the fibre results from damage to the neurone itself. In a third group its myelin sheath is disproportionately affected.

The current contributions of electrophysiological investigation, tissue biopsy, and animal experiment to the study of peripheral nerve lesions are discussed, and a brief account is given of the application of concepts drawn from these fields to some of the commoner clinical forms of neuropathy.

\section{REFERENCES}

Austin, J. H. (1958). Brain, 81, 157.

Brain, Lord, and Norris, F. H., jun. (1965). The Remote Effects of Cancer on the Nervous System. New York

Cavanagh, J. B. (1964). F. Path. Bact., 87, 365.

Cragg, B. G., and Thomas, P. K. (1964). भ. Neurol. Neurosurg. Psychiat., $27,106$.

Denny-Brown, D. (1951). Ibid., 14, 237.

Devadatta, S., Gangadharam, P. R. J., Andrews, R. H., Fox, W., Ramakrishnan, C. V., Selkon, J. B., and Velu, S. (1960). Bull. Wld Hlth Org., 23, 587.

Eldjarn, L., Try, K., Stokke, O., Munthe-Kaas, A. W., Refsum, S., Steinberg, D., Avigan, J., and Mize, C. (1966). Lancet, 1, 691 .

Evans, D. A. P., Manley, K. A., and McKusick, V. A. (1960). Brit. med. 7., 2, 485 .

Fullerton, P. M. (1966). F. Neuropath. exp. Neurol., 25, 214

Garland, 'H. (1955). Brit. med. f., 2, 1287.

Haymaker, W., and Kernohan, J. W. (1949). Medicine (Baltimore), 28, 59.

Hughes, H. B., Biehl, J. P., Iones, A. P., and Schmidt, L. H. (1954). Amer. Rev. Tuberc., 70, 266.

Kahlke, W. (1964). X!ın. Wschr., 42, 1011.

Klenk, E., and Kahlke, W. (1963). Hoppe-Seylers Z. physiol. Chem., 333, 133 .

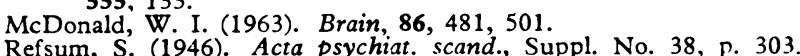

Refsum, S. (1946). Acta psychiat. scand., Suppl. No. 38, P. 303.

Wilkinson, P. C. (1954). Lancei, 1, 1301.

\title{
Interpretation of Levels of Strontium-90 in Human Bone
}

\author{
W. FLETCHER*; J. F. LOUTIT, $\dagger$ C.B.E., D.M., F.R.C.P., F.R.S. ; D. G. PAPWORTH†
}

Brit.med. F., 1966, 2, 1225-1230

Bones from various localities in Britain have been analysed for their content of strontium-90 since 1955. The results have been reported by Bryant and co-workers (1957, 1958a, 1958b, 1959a, 1959b, 1959c, Arden et al. 1960), and more recently by the Medical Research Council (1960-6). At intervals the results have been surveyed, and, in the light of what is known about the contamination of the "national diet" (Agricultural Research Council, 1959-65), deductions have been made about turnover of strontium in bone (Bailey, Bryant, and Loutit, 1960 ; Bryant and Loutit, 1961, 1964).

This communication is concerned particularly with new data derived since the considerable increase in fall-out following the 1961-2 nuclear-weapon detonations in the atmosphere.

\section{Materials and Analytical Methods}

The standard bone for assay in the national series has been the femur. However, for infants, as it has been shown that there is no difference in concentration of strontium-90 among different bones (Bryant and Loutit, 1961), any bone made available by the pathologist has been welcomed. Whenever possible the femur, whole or as a longitudinal section, has been used, and, less frequently, upper or lower sections. Occasionally other bones from adolescents have been supplied and analysed.

In addition, smaller surveys have been made on bones (vertebrae) collected on a more systematic basis in London in

* United Kingdom Atomic Energy Authority, Capenhurst Works, Chester. † Medical Research Council Radiobiological Research Unit, Harwell, Berkshire.
1961 (Bartlctt, Bryant, and Loutit, 1963) and 1963 and 1964 (Bartlett, Fletcher, and Loutit, 1966).

The method for assay of strontium-90 in bone after thermal ashing at $700^{\circ} \mathrm{C}$. has continued to depend upon the preferential solution of calcium by fuming nitric acid and the removal of barium and radium to isolate the strontium. In appropriate cases the yttrium-90 daughter is separated. The activity of the strontium and yttrium is measured by using geiger counters arranged in anticoincidence with an overall background of less than 1 count per minute. The natural strontium content is determined spectrographically, but for samples arising from the beginning of 1964 a preliminary separation of strontium from calcium by cation-exchange chromatography has been introduced. The methods have been published elsewhere (Bryant, Morgan, and Spicer, 1959a ; Webb and Wordingham, 1963).

\section{Results in National Series}

\section{Variation of Strontium-90 with Age}

The mean concentrations of strontium-90 in picocuries per gram of calcium ( $\mathrm{pCi} / \mathrm{g} . \mathrm{Ca}$ ) according to age for bones analysed for each of the years 1956 to 1964 are given in Figs. 1 and 2. As in the earlier years, so in the last three, maximum values were observed at around 1 year of age. The values thereafter fell progressively with age to minima in adults.

The time taken to reach the maximum concentration was short. In previous discussions (Bryant and Loutit, 1961, 1964) the observed data in each year for those less than 2 years 
old were plotted as concentration versus age. From these values a line of best fit (as judged by eye) of the mean values was drawn. In this way it appeared that a plateau value was reached by the age of 6 months. When the individual results were weighted for domicile by adjustment for the concentration of strontium-90 in the milk of the region, the same result was sbtairsed (Loutit, Russell, Bruce, and Bartlett, 1964), though there was little difference between the weighted values at 4 and
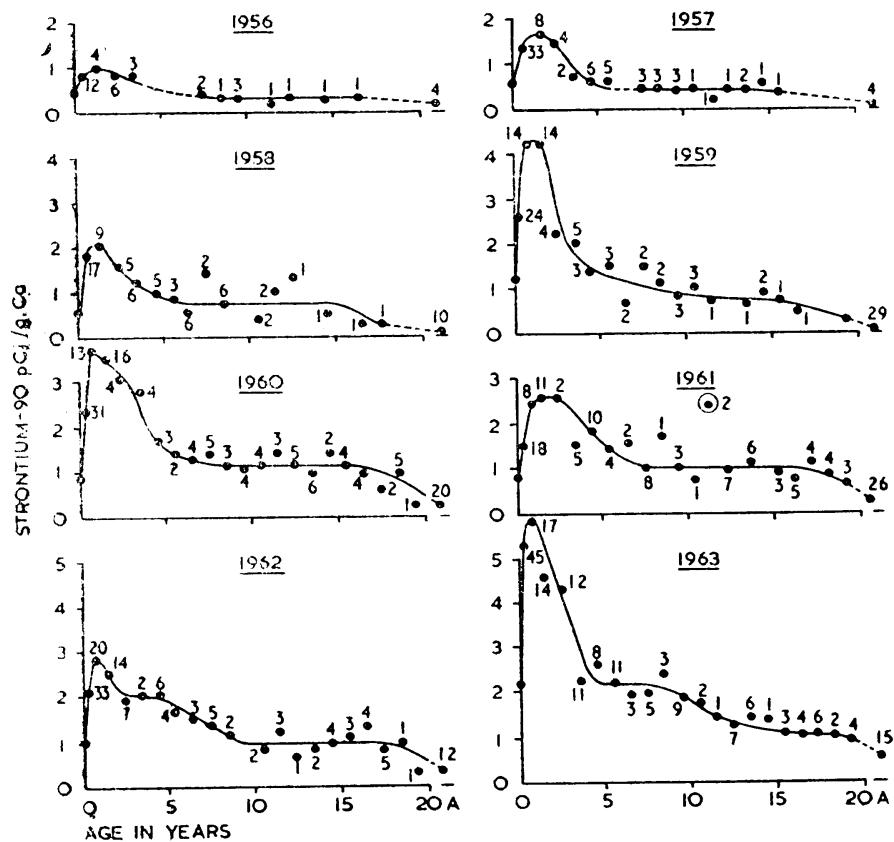

Fig. 1.-Concentration of strontium-90 (pCi/g. Ca) in human bone according to age, 1956-63. A = Adults. (Numerals indicate number of samples analysed.)

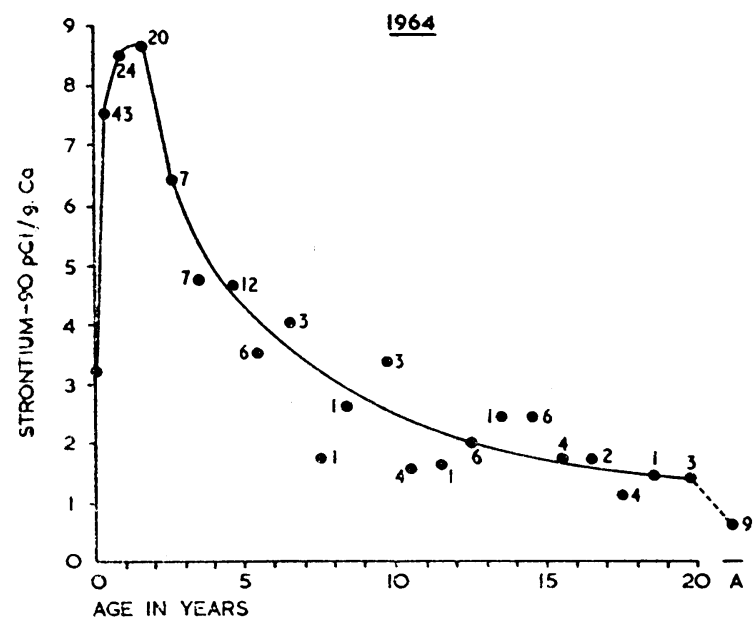

FIG. 2.-Concentration of strontium-90 (pCi/g. Ca) in human jone according to age in 1964. $\mathrm{A}=$ Adults. (Numerals indicate number of samples analysed.)

6 months. The unweighted values in 1964 suggests that the piateau was reached by the age of 4 months in that year (Fig. 3). Similar graphs for 1962 and 1963 are less revealing in that there was a general and progressive rise in values in each halfyear, and per half-year the total numbers of samples recorded were rather too few to be useful. Nevertheless, it appeared that plateaux were reached within 4 months-for example, the relative mean values for children $3-4$ and 5-23 months old respectively were $\frac{2.8 \text { (14 samples })}{3.0(26 \text { samples })}$ in the second half of 1962 and $\frac{4.4 \text { (10 samples })}{4.4(23 \text { samples })}$ in the first half of 1963 .

\section{Variation of Strontium-90 with Domicile}

Newborn.-The values in infants at birth reflect the status of the mothers' plasma and tissue fluids during the terminal stages of pregnancy. They are indicative, therefore, of current conditions in a special section of the adult community. Substantial numbers of samples from those dying during the first month of life have been regularly received from Wales, principally South Wales, and periodically from the London area and from Lancashire. Previously (Bryant and Loutit, 1961, 1964) no significant differences were found in a particular region and year between the means of samples from subjects aged 0 to 1 day and 1 day to 1 month. These results were then aggregated and applied to "newborn." In 1962-4 the values within the first month have been separated into age groups 0 and 1 day, 2-7 days, 8-14 days, and $15+$ days. From Table I it will be seen that the few samples usually obtained in the latter two groups do not influence the mean of the whole group under 1 month of age. In 1964, however, this is not so. Thus, in comparing the regional differences, values from the 0 - and 1-day-old infants are used. In each year these values for Wales are about $50 \%$ higher than those for Lancashire $1962(\mathrm{P}<0.001)$ and London 1963 and $1964(\mathrm{P}<0.001)$, and approximately the same as those determined for S.W. Scotland (M.R.C., 1960-6), the observed means Wales/Scotland being $1.11 / 1.05,2.35 / 2.66$, and 3.22/3.60 in 1962, 1963, and 1964 .

Infants 1 Month up to 2 Years Old.-The 87 observations given in Fig. 3 for 1964 have been assessed as formerly (Bryant and Loutit, 1964) by considering them according to broad regions-nameiy, Wales, Scotland and Borders, Midlands, and London and S.E. England (from Suffolk to Sussex) -and to whether they were intermediate (within $\pm 30 \%$ of the means of the whole group) or higher or lower than these limits. Hence Table II has been constructed. The results obtained on the small numbers of samples from Wales and the Border

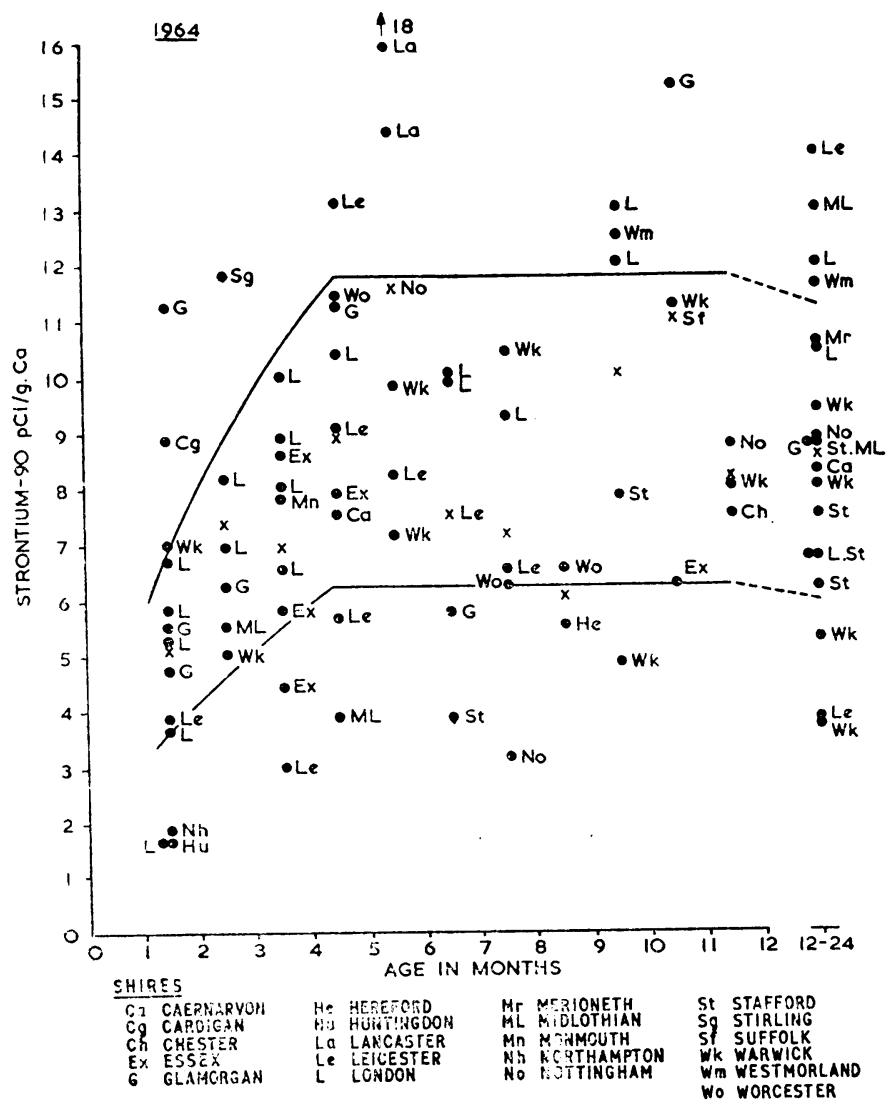

FIG. 3.-Data for 1964 on domicile of infan:s aged more than 1 month and less than 2 years whose bones were analysed for strontium-90. $=$ Individual result and domicile. $x=$ Mean of group. $-= \pm 30 \%$ of line of best fit through the means. 
country suggest that the degree of contamination of infants is greater in those regions than in the Midlands and the Southeast. The separate survey based on Glasgow (M.R.C., 1960-6, Nos. 10 and 11) confirm this, the results being: high 18; intermediate 20 ; low 6 .

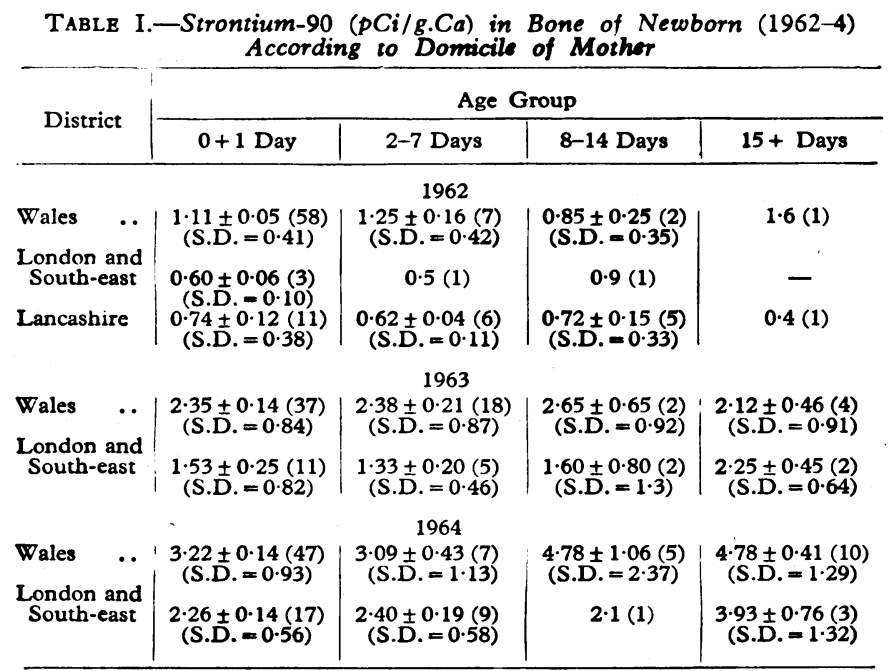

TABLB II.-Degree of Contamination of Bones of Infants from 1 Month up to 2 Years of Age According to Domicile-1964

\begin{tabular}{|c|c|c|c|c|}
\hline \multirow{2}{*}{\multicolumn{2}{|c|}{ Region }} & \multicolumn{3}{|c|}{ No. of Samples in Contamination Group } \\
\hline & & High & Intermediate & Low \\
\hline $\begin{array}{l}\text { Wales } 0 \text { Scotland and Borders } \ldots \\
\text { Midlands } \\
\text { London and South-east }\end{array}$ & $\begin{array}{l}\ddot{y} \\
\ddot{.}\end{array}$ & $\begin{array}{l}3 \\
4 \\
5 \\
3\end{array}$ & $\begin{array}{r}9 \\
2 \\
25 \\
21\end{array}$ & $\begin{array}{l}1 \\
1 \\
9 \\
4\end{array}$ \\
\hline
\end{tabular}

Children Aged 2+ Years and Adolescents.-In 196472 observations were spread over the 18 age groups 2-19 inclusive. Within any group the range of values did not exceed twofold, in contrast to the situation in infants, where values in a single class might vary threefold to fivefold (Fig. 3). The general picture of the 29 samples from Wales and the Border country was little different from that in the 43 samples from the Midlands and the South-east.

\section{Variation within Skeleton}

During the period few analyses were made of multiple bones from the same subject. These few are recorded in Table III.

The three adults all had gross disease of the bone or bonemarrow, so that these results are of little general significance. The figures for children and adolescents are in conformity with the previous scanty observations that the differences between

\begin{tabular}{|c|c|c|c|c|c|c|c|c|c|c|}
\hline \multirow{2}{*}{$\begin{array}{l}\text { Sub- } \\
\text { ject } \\
\text { HB } \\
\text { No. }\end{array}$} & \multirow[b]{2}{*}{ Sex } & \multirow{2}{*}{$\begin{array}{c}\text { Age } \\
\text { in } \\
\text { Years }\end{array}$} & \multirow[b]{2}{*}{ Diagnosis } & \multirow{2}{*}{$\left|\begin{array}{l}\text { Femur } \\
(\mathrm{pC} i / \\
\text { g. Ca })\end{array}\right|$} & \multicolumn{6}{|c|}{ Relative Values } \\
\hline & & & & & $\begin{array}{l}\text { Pat- } \\
\text { ella }\end{array}$ & Rib & Vert. & Calv. & $\begin{array}{l}\text { Pel- } \\
\text { vis }\end{array}$ & Tibia \\
\hline $\begin{array}{l}1214 \\
1475 \\
1476 \\
1477 \\
1488 \\
1493 \\
1511 \\
1640\end{array}$ & $\begin{array}{c}\mathbf{M} \\
\mathbf{F} \\
\mathbf{F} \\
\mathbf{F} \\
\mathbf{M} \\
\mathbf{M} \\
\mathbf{M} \\
\mathbf{M}\end{array}$ & $\begin{array}{c}14 \\
3 \\
3 \\
3 \\
17 \\
8 / 12 \\
12 \\
5\end{array}$ & $\begin{array}{l}\text { Encephalitis } \\
\text { Burns } \\
\text { " } \\
\text { M̈ult. injury } \\
\text { Amyotonia } \\
\text { Cong. heart } \\
\text { Acute } \\
\text { leukgmia }\end{array}$ & $\begin{array}{l}1 \cdot 0 \\
1.8 \\
1.4 \\
1.15 \\
0.9 \\
3.7 \\
0.95 \\
1.7\end{array}$ & $\begin{array}{l}1 \cdot 1 \\
= \\
\overline{-} \\
1 \overline{0}\end{array}$ & $\begin{array}{l}\overline{0.95} \\
0.79 \\
0.96 \\
1.04 \\
= \\
-\end{array}$ & $\begin{array}{l}\overline{1.06} \\
0 \cdot 86 \\
0.87 \\
1.00 \\
0.92 \\
-\end{array}$ & $\begin{array}{l}= \\
\bar{z} \\
0.77 \\
=\end{array}$ & $\begin{array}{l}= \\
\bar{z} \\
= \\
=\end{array}$ & $\begin{array}{l}= \\
= \\
\bar{z} \\
0.95\end{array}$ \\
\hline $\begin{array}{l}1746 \\
1747 \\
\end{array}$ & $\begin{array}{r}\mathbf{M} \\
\mathbf{F}\end{array}$ & $\begin{array}{c}15 / 12 \\
1 \\
\end{array}$ & $\begin{array}{l}\text { leukaemia } \\
\text { Burns } \\
\text { ", }\end{array}$ & $\begin{array}{l}1 \cdot 1 \\
8 \cdot 0 \\
8 \cdot 8 \\
\end{array}$ & 二 & $\begin{array}{l}\overline{1.02} \\
1.04 \\
\end{array}$ & $\begin{array}{l}1.0 \\
1.06 \\
1.02 \\
\end{array}$ & 二 & 二 & $\bar{z}$ \\
\hline $\begin{array}{l}1231 \\
1252 \\
1974\end{array}$ & $\mathbf{F}$ & $\begin{array}{l}84 \\
73 \\
50\end{array}$ & $\begin{array}{l}\text { Paget's } \\
\text { disease }\end{array}$ & $\begin{array}{l}0.26 \\
0.49 \\
0 \cdot 14\end{array}$ & $\begin{array}{l}1.4 \\
0.8 \\
\end{array}$ & $\begin{array}{l}0.9 \\
1.2 \\
2.9\end{array}$ & $\begin{array}{l}1.6 \\
1.8 \\
9.1\end{array}$ & $\begin{array}{l}1.4 \\
1.9 \\
3.2\end{array}$ & $1 . \overline{6}$ & $\bar{z}$ \\
\hline
\end{tabular}

bones in young children are inconspicuous and in adolescents considerably less than in adults.

Additionally, on 32 occasions the femur supplied was separated into upper and lower extremities and shaft (cf. Bryant and Loutit, 1961), and these portions were analysed separately. The results are given in summary in Table IV.

TABLE IV.-Concentration of Strontium-90 ( $\mathrm{Ci} / \mathrm{g} . \mathrm{Ca})$ in Three Portions of Femur Relative to that of the Weighted Mean of Whole Femur. Meist

\begin{tabular}{|c|c|c|c|c|c|}
\hline Age (years): & $<5$ & $5-9$ & $10-14$ & $15-19$ & $20+$ \\
\hline No. of samples: & 9 & 7 & 8 & 4 & 4 \\
\hline 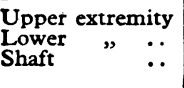 & $\begin{array}{l}1.16 \pm 0.16 \\
1.15 \pm 0.08 \\
0.92 \pm 0.04\end{array}$ & $\begin{array}{l}1.12 \pm 0.10 \\
1.18 \pm 0.14 \\
0.91 \pm 0.05\end{array}$ & $\begin{array}{l}1.19 \pm 0.08 \\
1.18 \pm 0.08 \\
0.89 \pm 0.04\end{array}$ & $\begin{array}{l}1.18 \pm 0.14 \\
1.20 \pm 0.15 \\
0.92 \pm 0.06\end{array}$ & $\begin{array}{l}1.84 \pm 0.25 \\
0.95 \pm 0.25 \\
0.72 \pm 0.06\end{array}$ \\
\hline
\end{tabular}

Hitherto the numbers of femurs so analysed were sufficien only to give the pattern in adults, which conformed to that in the fou samples reported in the final column of Table IVnamely, the upper extremity having about twice the concentration of strontium-90 and the shaft about two-thirds that of the femur as a whole. The pattern in children and adolescents was less clear owing to paucity of samples, but was certainly in conformity with the results in Table IV-namely, that there is little difference between the two extremities, in each of which the strontium-90 is about $15 \%$ higher than the whole femur, whereas the concentration in the shaft is about $10 \%$ lowex than in whole femur. There appears from these results to be no trend with age in growing subjects; the pattern is the same in each group, but quite different from that in adults.

\section{Results in West London Series}

Adults.-The one striking difference between results in this series and the national series is shown in Table $V$, the

TABLE V.-Mean Strontium-90 (pCl/g. Ca) in Adult Bone in Two Series (and Numbers of Samples Contributing to the Mean)

\begin{tabular}{|c|c|c|c|c|}
\hline Series & & 1951 & 1963 & 1964 \\
\hline $\begin{array}{l}\text { W. London (vertebral bone) } \\
\text { National (femoral bone) }\end{array}$ & $\because$ & $\begin{array}{l}0.68(48) \\
0.33(25)\end{array}$ & $\begin{array}{l}0.85(48) \\
0.54(15)\end{array}$ & $\begin{array}{l}1.5(44) \\
0.54(9)\end{array}$ \\
\hline
\end{tabular}

strontium-90 concentration in adult bone from West London being numerically higher. Within this series Bartlett et al. (1963) found no appreciable difference between the age groups $20-49(0.67 \pm 0.037 \mathrm{pCi} / \mathrm{g}$. $\mathrm{Ca})$ and $50+(0.69 \pm 0.027)$ in 1961 ; the relative results were similar in the later years- -0.9 and 0.8 in 1963 and 1.5 and 1.5 in 1964 (Bartlett et al., 1966).

Newborn.-In 1961 the nine samples from infants 0-2 weeks of age had an average value $(0.69 \mathrm{pCi} / \mathrm{g}$. Ca) much the same as that in the larger national series (124 samples, mean 0.72 ) (Bartlett et al., 1963) but higher than the average of the 22 samples from London and Home Counties $(0.60 \pm 0.03)$ (Bryant and Loutit, 1964). In 1963 the same bias was observed. The mean values for infants $0-1$ month of age were 1.8 (20 samples in 1963) and 3.3 (15 samples in 1964). The mean values for 0 - + 1-day-old infants were similar: $1.8 \pm 0.23$ (12 samples in 1963) and $3.2 \pm 0.30$ (8 samples in 1964), compared with values in Table I $1.53 \pm 0.25$ and $2.26 \pm 0.14$ for London and S.E. England within the national series.

Infants, Children, and Adolescents.-In 1964 the values for infants over 1 month and less than 2 years of age, if related to Fig. 3, would have been classified high: intermediate: low $=$ $1: 11: 1$. Values for 13 children between 2 and 9 years old were scattered round the mean value drawn in Figs. 1 and 2, while the 13 values for adolescents 10-19 years old suggested mean values about $50 \%$ greater in the late teenages.

In 1963, when values were rising through the year, the general pattern was similar. 


\section{Interpretations}

\section{Diets}

The mean figures for the National Diet in the three years have been estimated as $10,23,26 \mathrm{pCi} / \mathrm{g}$. Ca (Agricultural Research Council (1959-65), Reports Nos. 10, 12, 14). Regional variations may be deduced. The mean can be taken to apply in the Midlands (which for this purpose includes Lancashire and Yorkshire) and London-the great centres of population ; it will overestimate the situation in the drier parts of East and South-east England and will underestimate the dietary contamination in the wetter but less populous regions of Wales and Scotland. In the latter regions the milk, which provides roughly half of the strontium-90 and of the calcium in the national diet, is usually about $40 \%$ higher than the national mean. The regional diets in Wales and Scotland might thus be some $20 \%$ to $30 \%$ higher than the estimated values for national diet, if other locally produced fresh foods are important sources.

\section{Adult Bone}

Effort has been concentrated in the national series on analysing bones from growing subjects. Thus only few observations have been made on adults.

The observed mean values of $0.32,0.54$, and 0.5 for 12,15 , and 9 samples of femur respectively in 1962,1963, and 1964 are still in accord with previous estimates of a mean " rate of replacement" of pre-existing strontium in femora with current dietary strontium calculated as $1.6 \%$, range $1.1-2.6 \%$, per year (Bryant and Loutit, 1961) and $2.9 \%$, range 1.2-5.6\% (Bryant and Loutit, 1964). These are underestimates of the average rate for the whole skeleton.

In the U.K. no analyses have been made on whole cadavers. Between 1950 and 1959 Kulp and Schulert (1962) in the U.S.A. performed over 500 such analyses. The following ratios of relative activity of strontium-90 were derived:

$$
\frac{\text { vertebra }}{\text { skeleton }}=2.1 ; \frac{\text { rib }}{\text { skeleton }}=1.4 ; \frac{\text { long bone shaft }}{\text { skeleton }}=0.45 \text {. }
$$

These relative values will not be valid for all time and all conditions, but probably represent a fair guide for some time to come. In previous reports (Bryant and Loutit, 1961, 1964) limited data were given for concentration of strontium-90 in multiple bones from the same subjects. Then it was estimated that the "rate of replacement" was $2.1-6.2 \%$ (mean $3.6 \%$ ) per year and $2.2-10.0 \%$ (mean $4.7 \%$ ) per year for ribs analysed in 1959 and 1961 respectively. For vertebrae of the same subjects the mean rate of replacement was calculated as $8.3 \%$ in both 1959 and 1961 .

In most countries vertebrae are selected for analysis (United Nations, 1964-Annex A, Table XX). Thus recorded values of strontium-90 in adult bone are higher, even though fall-out may be less, than in the U.K., which is in the latitudinal band of maximum deposition. The latest reports from the U.S.A. (Rivera, 1965) give values averaging $2.0,1.5$, and $1.2 \mathrm{pCi} / \mathrm{g} . \mathrm{Ca}$ in vertebrae of adults in New York City, Chicago, and San Francisco. The corresponding figures for diet were 32, 20, and $14 \mathrm{pCi} / \mathrm{g}$. Ca respectively. A rate of replacement of $9 \%$ per year was calculated from the data.

In the West London survey, where vertebrae, not femora, are analysed, values of $0.68,0.85$, and $1.5 \mathrm{pCi} / \mathrm{g}$. Ca were obtained in 1961, 1963, and 1964. The differences between numerical values in Table $\mathrm{V}$ are entirely accountable to the bone analysed. The lag between contamination of food and its appearance in bone is alsn notable.

Compared with those in the prime of adult life (20-49) the senescent and senile, with presumably some physiological osteoporosis, showed no decrease in concentration of strontium-90; even those with certified pathological osteoporosis had no un- duly low values. These observations conform with present views that do not favour the Albright hypothesis relating osteoporosis to impaired osteogenesis (Albright et al., 1941).

\section{Children and Adolescents}

The previous calculations of rate of replacement (Bryant and Loutit, 1961, 1964), whether for children and adolescents or adults, have been questioned because they were based on considerations of specific activity- ${ }^{90} \mathrm{Sr} / \mathrm{mg}$. Sr. It is admitted that there is appreciable local variation in stable strontium (Mole, 1965) and that strontium is not itself controlled homoeostatically as is calcium.

The alternative methods of calculation involve strontium: calcium relationships and the much used and abused observed ratio of Comar et al. (1956). Effectively the observed ratio $\mathrm{Sr} / \mathrm{Ca}$ bone

$\mathrm{Sr} / \mathrm{Ca}$ diet is a measure under certain defined conditions of the total discrimination by the body against strontium in favour of calcium. The abuse of observed ratio consists in applying it under conditions other than those defined by Comar et al.

Rivera (1963) adapted a formula from Kulp and Schulert (1962) to calculate the best values of both observed ratio and the "rate of exchange"-that is, "rate of replacement" in our terminology - of bone and dietary strontium-90.

Rivera's calculation referred to children aged 1 to 5 years, and the following values were derived:

$$
\begin{array}{ll}
\mathrm{F} \text { (fraction of skeleton exchanged/year) } & =0.51 \pm 0.20 \\
\mathrm{~K} \text { (observed ratio) } & =0.24 \pm 0.01
\end{array}
$$

Data are available in the U.K. of the ${ }^{90} \mathrm{Sr} / \mathrm{Ca}$ ratio in national diet from 1958 to 1964 (Agricultural Research Council (195965) Reports). Less extensive data for 1957 are obtained from Bryant et al. (1958a). Since the ratio of the ${ }^{9} \mathrm{Sr} / \mathrm{Ca}$ ratios, milk products: non-milk products, is approximately $1: 1$, and, as the amounts and distribution of non-milk products in diets of infants and children are inconstant and uncertain, it was assumed that values for the national diet (see Table VI) could be applied. (Some justification for this is derived from calculations in Bryant and Loutit, 1961).

TABLE VI.-Values Used for Contamination of National Diet in Calculations of Rate of Strontium Replacement

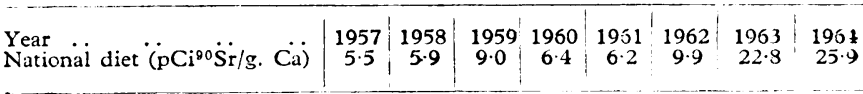

Data on bones were derived from the years 1957-64 by reading from Figs. 1 and 2 the interpolated values for the ages $1,2,3$, etc., in each year.

Although the intake of strontium-90 varies with the place of residence, inspection of the raw data and some pilot exercises on weighting individual values according to domicile suggested that such weighting made little difference in the resulting means. Thus unweighted means were used.

Calculations from the formula given by Rivera produced the following values for the sequential data for 1958-63:

Direct correlation: $\mathrm{F}=0.25 \pm 0.08 ; \mathrm{K}=0.19 \pm 0.02$.

Lagged correlation-that is, when diet values not of the current but the previous year were used-F=0.59 $\pm 0.15 ; \mathrm{K}=0.29 \pm 0.02$.

Thus over the longer term in the U.K. the lagged correlation gave a better fit with the more limited data for the American cities.

It is doubtful if the observed ratio concept has any validity in a changing situation. Therefore, to avoid its use, another formula, which considers strontium-90 only, was used, namely: $\left[{ }^{\circ 0} \mathrm{Sr}\right]_{\mathrm{n}}=\left(1-\mathrm{p}^{\prime}\right)\left[{ }^{\circ 0} \mathrm{Sr}\right]_{\mathrm{n}-1}+\mathrm{P}\left(1-\mathrm{p}^{\prime \prime}\right) \mathrm{D}$

where the new symbols are:

$\left[{ }^{90} \mathrm{Sr}\right]_{\mathrm{n}-1}$ and $\left[{ }^{\circ 1} \mathrm{Sr}\right]_{\mathrm{n}}$ denote body content of strontium-90 at the end of $(n-1)^{\text {th }}$ and $n^{\text {th }}$ year of age-that is, calcium content assumed for age (Mitchell et al., 1945) $\times$ observed mean ${ }^{\circ} \mathrm{Sr} / \mathrm{Ca}$ concentration in femora. 
$\mathrm{p}^{\prime}$ is the fraction of the existing body burden of ${ }^{\circ 0} \mathrm{Sr}$ at the beginning of a year excreted during the year.

$P$ is the fraction of ingested ${ }^{\circ} \mathrm{Sr}$ absorbed by the gut from the diet.

$\mathrm{p}^{\prime \prime}$ is the fraction of the absorbed dietary ${ }^{90} \mathrm{~S} r$ of the year excreted during the year.

$D$ is the ${ }^{\circ 0} \mathrm{Sr}$ ingested in a year-derived from an assumed intake of $365 \mathrm{~g}$. $\mathrm{Ca} \times{ }^{00} \mathrm{Sr} / \mathrm{Ca}$ ratio of diet. Experience shows that there is a lag of about 6 to 12 months before bone reflects a rise or fall in the ${ }^{\circ 0} \mathrm{Sr} / \mathrm{Ca}$ value of the national diet. Therefore, for the ${ }^{\circ 0} \mathrm{Sr} / \mathrm{Ca}$ ratio used to derive $\mathrm{D}$ a mean of the current and previous years' values was taken (see Table VI). Values of $\left(p^{\prime}\right)$ and $P\left(1-p^{\prime \prime}\right)$ were estimated by the method of least squares and are given in Table VII.

TABLE VII.-Values Derived for $p^{\prime}-$ Fraction of Strontium-90 Burden Excreted-and $P\left(1-p^{\prime \prime}\right)-F r a c t i o n$ of Dietary Strontium-90 Retained - Per Year According to Age

\begin{tabular}{c|c|c|c|c|c}
\hline Age (years) & $\mathrm{p}^{\prime}$ & $\mathbf{P}\left(1-\mathrm{p}^{\prime \prime}\right)$ & Age (years) & $\mathbf{p}^{\prime}$ & $\mathbf{P}\left(1-\mathrm{p}^{\prime \prime}\right)$ \\
\hline $1-2$ & 0.51 & 0.097 & $11-12$ & 0.16 & 0.061 \\
$2-3$ & 0.52 & 0.077 & 12.13 & 0.13 & 0.063 \\
$3-4$ & 0.49 & 0.065 & $13-14$ & 0.12 & 0.066 \\
$4-5$ & 0.64 & 0.077 & $14-15$ & 0.13 & 0.069 \\
$5-6$ & 0.62 & 0.075 & $15-16$ & 0.12 & 0.069 \\
$6-7$ & 0.58 & 0.074 & $16-17$ & 0.19 & 0.075 \\
$7-8$ & 0.63 & 0.079 & $17-18$ & 0.18 & 0.070 \\
$8-9$ & 0.53 & 0.077 & $18-19$ & 0.26 & 0.071 \\
$9-10$ & 0.38 & 0.070 & $19-20$ & 0.47 & $0.08 J$ \\
$10-11$ & 0.25 & 0.066 & & & \\
\hline
\end{tabular}

The values obtained in this way, relating to the experience of eight years, suggest a remarkably uniform performance. Each year from the ages of 1 to 9 about half the existing body burden of strontium-90 is apparently lost. After that the fraction lost falls to 0.1 to 0.2 per year, apart from the final value. Throughout infancy and adolescence the calculations indicate a remarkably constant retention at the end of each year of about $7 \%$ of that year's dietary intake.

Necessarily, there are uncertainties about $\cdot$ such calculations. The postulated daily intake of $1 \mathrm{~g}$. $\mathrm{Ca}$ at each age is at best only an approximation based on indirect data, but is a reasonable and standard assumption. The deduction of body burden rests on the few observations of Mitchell et al. (1945) for body calcium in American subjects. This assumed calcium burden is multiplied by the observed ${ }^{90} \mathrm{Sr} / \mathrm{Ca}$ ratio in femora. This ratio is certainly not representative of total skeleton in adults (see above). Nevertheless, Table IV shows that in adolescents compared with adults there are only small differences in concentration between the actively growing extremities of the bone and the main bulk, the shaft. Thus the whole femur is likely to give only a small underestimate in adolescents of mean skeletal concentration. For these and other reasons no standard deviations which might be adduced for the derived values of $\mathrm{p}^{\prime}$ and $\mathrm{P}\left(1-\mathrm{p}^{\prime \prime}\right)$ are quoted. Finally, the small annual radioactive decay of strontium-90 $\left(\mathrm{T}_{\frac{1}{2}}-28 \mathrm{y}\right)$ has been neglected.

\section{Infants}

It would be of physiological interest to assess turnover or replacement of strontium-90 perhaps month by month in the bones of infants less than a year old. However, the method used for children, while admissible in principle, is much more difficult to apply in practice. First, the diet of infants appears from the surveys (Durnin, unpublished) to be extraordinarily variable, certainly in S.W. Scotland, and probably in Britain. This could account for the wide range of values in young infants (see Fig. 3). Secondly, contamination of milk is a variable from month to month within most years (Agricultural Research Council reports), so that unless the source of this main constituent of diet-currently produced fresh milk or dried milk-is known, the calculation becomes uncertain. Observations in individual infants by the metabolic balance method

${ }^{2}$ An error of $x \%$ in estimating $D$ has no effect on $p^{\prime}$, but $P\left(1-p^{\prime}\right)$ would need to be multiplied by $100 /(100+x)$.
(Lough et al., 1963 ; Straub, personal communication) suggest that there is on average little total discrimination between strontium and calcium in that the observed ratio ${ }^{90} \mathrm{Sr} / \mathrm{Ca}$ retained

${ }^{90} \mathrm{Sr} / \mathrm{Ca}$ diet $=1$. However, the errors of the balance method-retention being assessed as a difference of two large numbers and the particular difficulties associated with small activities of strontium-90-may have introduced bias. It is difficult to see how the marked differences found in survey between actual bone and presumed diet values could be resolved if discrimination of strontium and calcium were virtually absent. Indeed, short-term balance studies in infants reported from Harwell (Harrison et al., 1965) show that the $\mathrm{Sr} / \mathrm{Ca}$ ratio in urine is several times that in diet, indicative of renal discrimination. The situation is entirely understandable if bone in the infant were resorbed in remodelling after a half-life of weeks or months. The strontium and calcium of the resorbed bone when in the circulation would then be subject to repeated chance of renal discrimination.

\section{Newborn}

The values given in Table I support previous observations in man and experiments on animals that strontium-90 in neonatal bone is about one-tenth the concentration in maternal diet, indicative of maternal-foetal discrimination of strontium and calcium across the placenta.

The values are also in accord with geographic expectation except in so far as groups of samples from within the London area show significant differences. Differences between mortuaries in exogenous contamination could obviously be one factor ; channels of food distribution, especially milk within a large metropolis, could be another ; notoriously, London is an obstetric haven with accommodating addresses for unmarried mothers from the provinces, but the principal reason may well be the small numbers within the groups.

\section{Summary}

The results of analysis of human bone for strontium-90 in 1962-4 reflect the increase of contamination of food following the massive testing of nuclear weapons in 1961-2.

Maximum concentrations within any one year continue to occur in infants around 1 year old, and this maximum is reached at about 4 months of age. The individual values in infants vary widely, but the general levels in the wetter areas, Wales and Scotland, are slightly higher than in the Midlands and Southeast England.

In children and adolescents values are lower and much less variable between individuals and domicile. In contrast with adults, many of whose bones-for example, vertebrae-show substantially higher concentrations than others, there is little variation within the skeleton in children and even adolescents.

It is thus not unrealistic in juveniles to take the concentrations of strontium-90 observed in one bone as representative of the whole skeleton, and thus to derive body burdens according to age and year. With further data on observed contamination of diet it is calculated that the fractional loss of the strontium-90 body burden each year is about 0.5 until the age of 8 , falling to $0.1-0.2$ in adolescence. It is further calculated that the fractional retention of dietary strontium-90 is about 0.07 each year throughout childhood and adolescence.

\section{REFERENCES}

Agricultural Research Council (1959-65). Radiobiological Laboratory Reports, Nos. 1, 3, 5, 8, 10, 12, 14. H.M.S.O., London.

Albright, F., Smith, P. H., and Richardson, A. M. (1941). F. Amer. med. Ass., 116, 2465. 
Arden, J. W., Bryant, F. J., Henderson, E. H., Lloyd, G. D., and Morton, A. G. (1960). A.E.R.E.-R.3246. H.M.S.O. London.

Bailey, N. T. J., Bryant, F. J., and Loutit, J. F. (1960). A.E.R.E.-R.3299. H.M.S.O., London.

Burtlett, B. O., Bryant, F. J., and Loutit, J. F. (1963). In M.R.C. Monitoring Report Series, No. 6. H.M.S.O., London.

- Fletcher, W., and Loutit, J. I. (1966). Ibid., No. 12. H.M.S.O., London.

J.sant, F. J., Chamberlain, A. C., Morgan, A., and Spicer, G. S. (1957). i.E.R.E. HP/R 2353. H.M.S.O., London.

Spicer, G. S., and Webb, M. S. W. (1958a). Brit. med. 7., 1371 .

Henderson, E. H., Spicer, G. S., and Webb, M. S. W. (1958b). A.E.R.E. C/R 2583. H.M.S.O., London.

Morgan, A., and Spicer, G. S. (1959a). A.E.R.E.-R.3030. H.M.S.O., London.

H.M.S.O., London.

Cotterill, J. C., Henderson, E. H., Spicer, G. S., and Webber, T. J. 1959c). A.E.R.E.-R.2988. H.M.S.O., London.

and Louti, J. F. (1961). A.E.R.E.-R.3718. H.M.S.O., London.

(1964). Proc. roy Soc. B, 159, 449.
Comar, C. L, Wasserman, R. H., and Nold, M. M. (1956). Proc. Soc exp. Biol (N.Y, 92, 859 .

Harrison, G. E., Sutton, A., Shepherd, H., and Widdowson, E. M. (1963) Brit. F. Nutr., 19, 111 .

Kulp, J. L., and Schulert, A. R. (1962). Science, 136, 619.

Lough, S. A., Rivera, J., and Comar, C. L. (1963). Proc. Soc. exp. Kust (N.Y.), 112. 631

Loutit, J. F., Russell, R. S., Bruce, R. S., and Bartett, B. O. (196) Nature (Lona.), $201,770$.

Medical Research Council (1960-6). Monitoring Report Series, No: 1-i-, Section A. H.M.S.O., London.

Mitchell, H. H., Hamilton, T. S., Steggerda, F. R., and Bean, H. (1945). F. biol. Chem., 158, 625.

Mole, R. H. (1965). Brit. 7. Nutr. 19, 13.

Rivera, J. (1963). Radiological Health Data, 4 (11), 570.

(1965). U.S. Atomic Energy Commission Heaith and SateLaboratory, Quarterly Report, July 1965. HASL 161, p. 296. Ne. York.

United Nations (1964). Scientific Committee on the Effects of Atoms Radiation. General Assembly Official Records: Nizeteenth Sesslo: Suppl. No. 14 (A/5814). United Nations, New York.

Webb, M. S. W., and Wordingham, M. L. (1963). Knalyt. chim Acts 28, 450 .

\section{Adult Coeliac Disease in Tropics}

\section{R. C. MISRA,* M.D.; D. KASTHURI,* м.D. ; H. K. CHUTTANI,* M.D., D.T.m}

1its. med. $9,1966,2,1230-1232$

Trimary malabsorption syndromes occurring in the tropics vere generally regarded as examples of tropical sprue, and senzitivity to gluten was not thought to be a significant netiological factor. Even when steatorrhoea occurred among Europeans in those regions it was attributed to tropical sprue, snd the possibility of coeliac disease or idiopathic steatorrhoea was usually not considered. Before the recognition of glutensensitivity in the causation of coeliac disease this illness was thought to be a separate entity from tropical sprue, chiefly because of its onset in early childhood and its chronic and often progressive course.

Recently, when working on the aetiology of malabsorption in North India, we found that, though most of the cases of primary malabsorption were examples of tropical sprue, there Fere a few cases of gluten-sensitive enteropathy among them. We came across patients who failed to show a favourable response when treated on the usual lines for tropical sprue. When they were further analysed and investigated the diagnosis of adult coeliac disease became obvious. The diagnostic evidence consisted of the clinical and biochemical features, the jejunal mucosal appearances, a favourable response to a glutenfree diet, and the occurrence of symptoms in certain patients is both their childhood and their adulthood.

Intestinal biopsy now affords an important criterion for the ciagnosis of the disease. The presence of mucosal changes has teen noted in a variety of diseases, but a severe lesion (flat nucosa) is usually a feature of coeliac disease if tropical sprue has been excluded (Fone et al., 1960 ; Rubin et al., 1960a ; Girdwood et al., 1961; Cooke et al., 1963). Adult coeliac isease being the only recognized condition that responds to a eluten-free diet, the demonstration of the characteristic mucosal iesion and a favourable response to dietary therapy with relapse on reintroduction of gluten into the diet provide between them a fairly accurate basis for its diagnosis.

The present study aims to report seven cases of adult coeliac disease occurring in the tropics.

\section{Material and Methods}

This study was conducted at Irwin Hospital, New Delhi. Seven cases of suspected coeliac disease were investigated and

- Gastroenterology Unit of Department of Medicine, Maulana Azad Medical College, New Delhi. followed from 3 to 30 months while they were on a gluten-irex diet.

The patients were investigated by three-day quantitasire determinations of stool fat (van de Kamer et al., 1949), the D-xylose test as described by Santini et al. (1961), a baritimmeal follow-through study with a non-flocculable barium suspension, and small-bowel biopsy performed by means of a Crosby capsule (Crosby and Kugler, 1957) before and at intervals after the gluten-free diet was begun. Three grades were recognized in the histological evaluation of the biopsy specimens. Grade I consisted of mild-to-moderate changes. characterized by the irregularity of the surface epithelium increased cellular infiltration of the lamina propria, and stunting of villous height. In grade 2 these changes were more advariced (partial villous atrophy), and grade 3 was characterized by subtotal villous atrophy, glandular hypertrophy, marked round-cell infiltration of the lamina propria, and epithelial cell degenerstion.

\section{Results}

Details of the seven cases are given in the Table. In tive cases the disease started in childhood and continued wish remissions and exacerbations up to adulthood. In one patient (Case 7) there was a possible positive family history in that one of his elder sisters had died of chronic diarrhoea. Al except two patients (Cases 2 and 4) were stunted in growth They came to hospital either because of troublesome diarrhoes or because of stunted growth. All seven complained of weakness and loss of weight and were having diarrhoea of varyins severity. Abdominal distension was noted by four, symptoms of anaemia by two, and stomatitis by four. A history of tetary was elicited in only one patient, and none had paraesthesiae. a bleeding tendency, bone pains, or oedema over the feet.

\section{Response to a Gluten-free Diet}

\section{Clinical}

To give a fair trial to this sort of therapy it is important to eliminate completely wheat, barley, oats, and their products from the diet. Strict adherence to the prescribed diet is necessary for judging the success of diet therapy. After six weeks 